\title{
Factor X Activity Measurement
}

National Cancer Institute

\section{Source}

National Cancer Institute. Factor X Activity Measurement. NCI Thesaurus. Code C122118.

The determination of the amount of the biological activity of factor $\mathrm{X}$ in a sample. 